\title{
Gluten challenge in treated coeliac disease
}

\author{
S. M. PACKER, V. CHARLtON, J. W. KEELING*, R. A. RISDON $\dagger$, D. OGILVIE, \\ R. J. ROWLATT, V. F. LARCHER, AND J. T. HARRIES
}

From The Hospital for Sick Children, Great Ormond Street, and the Institute of Child Health, London

SUMMARY Thirty-two children with a past diagnosis of coeliac disease were reinvestigated by means of gluten challenge. They had received a gluten-free diet for a mean period of $6 \cdot 5$ years (range $0 \cdot 25-11 \cdot 0$ ) before gluten challenge, and had a mean age of $9 \cdot 9$ years (range $3 \cdot 0-15 \cdot 3$ ) at the onset of challenge.

Small intestinal biopsies were performed before and after the gluten challenge (at least $10 \mathrm{~g}$ natural gluten per day for 3 months in the majority) and, as judged by light microscopy and morphometric techniques, coeliac disease was confirmed in $25(78 \%)$ of the 32 patients; challenge was continued in the remaining 7 for a total period of 2 years when biopsies were repeated in 6 children and all were normal. Serum and RBC folate, serum iron, $\mathrm{Hb}$ level, and clinical symptoms were unpredictable variables in identifying children who developed gluten-induced enteropathies. The social and emotional effects of gluten challenge are discussed. The results highlight the importance of gluten challenge and intestinal biopsy in the diagnosis of coeliac disease and strongly suggest that a normal biopsy after a 3-month gluten challenge (as described above) excludes coeliac disease.

Intolerance to dietary gluten is a permanent phenomenon in true coeliac disease (Mortimer et al., 1968; Sheldon, 1969; Young and Pringle, 1971; Hamilton and McNeill, 1972) and there is an increased risk of neoplasia in affected adult patients (Harris et al., 1967; Barry and Read, 1973) which may be reduced by treatment with a strict gluten-free diet (Harris et al., 1967; Holmes et al., 1976). The application of strict diagnostic criteria (Meeuwisse, 1970) is thus of paramount importance to both child and family, and includes demonstration of abnormalities of the small intestinal mucosa induced by the ingestion of gluten. The timing of diagnostic biopsies during a gluten challenge is largely empirical particularly in those patients who remain asymptomatic, and the optimum duration of a gluten challenge has not been established.

We present results of a study designed to reappraise a past diagnosis of coeliac disease in a group of children who were being treated with a gluten-free diet. The effects of a gluten challenge on the intestinal mucosa and the clinical, emotional, and haematological effects of the challenge are reported.

Received 21 November 1977

Present addresses: *Department of Pathology, John Radcliffe Hospital, Headington, Oxford

†Morbid Anatomy, London Hospital Medical College, Whitechapel, London

\section{Patients and methods}

Thirty-two children were studied (Table 1) of whom one had a family history of coeliac disease. 11 patients had had a biopsy on at least one occasion. All biopsies were reviewed by one of us without knowledge of clinical details.

At the onset of the challenge 31 of the 32 patients had received a gluten-free diet (GFD) for at least 1 year with a mean and range of 6.5 and 0.25 to 11 years respectively. One patient, a 13-year-old girl, had received a GFD for only 3 months before the challenge. All 32 patients had shown clinical improvement on a GFD.

\section{Design of the study (Fig. 1)}

Initially an empirical period of 2 months was chosen as the challenge period, but this was increased to 3

\section{Table 1 Details of the patients studied}

\begin{tabular}{ll}
\hline $\begin{array}{l}\text { Number (M:F) } \\
\text { Mean age at time of original diagnosis } \\
\text { (years) (range) }\end{array}$ & $32(18: 14)$ \\
$\begin{array}{c}\text { Mean duration of gluten-free diet at onset } \\
\text { of gluten challenge (years) (range) }\end{array}$ & $2 \cdot 4(0 \cdot 3-13 \cdot 5)$ \\
$\begin{array}{c}\text { Mean age at onset of gluten challenge } \\
\text { (years) (range) }\end{array}$ & $6 \cdot 5(0 \cdot 25-11 \cdot 0)$ \\
$\begin{array}{c}\text { No. of patients who received a biopsy at } \\
\text { time of original diagnosis }\end{array}$ & $9 \cdot 9(3 \cdot 0-15 \cdot 3)$ \\
\hline
\end{tabular}




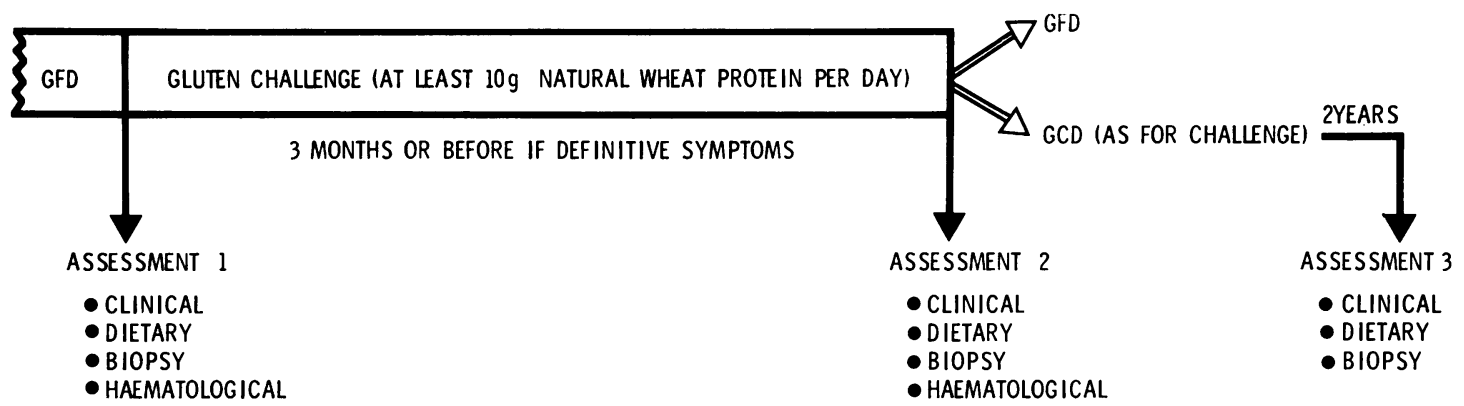

Fig. 1 Design of the study. GFD = gluten-free diet; $G C D=$ gluten-containing diet.

months provided the children remained symptom free. Before administering the gluten challenge the patients were admitted and assessed as shown in Fig. 1. A careful clinical and dietetic history was obtained. The mother was interviewed on at least two separate occasions for detailed dietary assessment. After an overnight fast a mucosal biopsy specimen was obtained, under fluoroscopic control, just distal to the duodenojejunal flexure. Blood samples were obtained by venepuncture and/or finger prick for $\mathrm{Hb}$, serum iron and folate, and red cell folate estimations. The patients were then given a gluten-containing diet (at least 4 slices of bread per day which is equivalent to $10 \mathrm{~g}$ gluten) and discharged home.

After the 3-month challenge period the patients were readmitted and assessed in a similar way to that during the first admission. The pre- and postchallenge biopsies were compared. 3 patients developed definite symptoms of gluten intolerance and were readmitted before the end of the 3-month period. The second admission of 6 patients was delayed for periods ranging from 16 to 56 weeks after the introduction of a gluten-containing diet for a variety of reasons (e.g. school commitments). When the children returned home after the second assessment parents were asked to complete a questionnaire in order to assess the emotional and social effects of the study on the children.

If the postchallenge biopsy was abnormal, GFD was reintroduced and the child assumed to have permanent gluten intolerance. If the postchallenge biopsy was normal the patient was followed as an outpatient and intestinal biopsy repeated 2 years later.

Surface to volume ratios $(\mathrm{C} / \mathrm{l} \mathrm{h})$ were measured in all biopsy specimens (Risdon et al., 1975). When counts fell within the normal range $(26 \cdot 3-56 \cdot 0)$ the biopsies were regarded as 'normal'. Where counts were in the range previously found in untreated coeliacs $(4 \cdot 7-14 \cdot 3)$ the biopsies were described as 'subtotal villous atrophy', and when counts fell in between the two ranges (i.e. 14·3-26.3) the biopsies were described as showing 'partial villous atrophy'.

\section{Results (Table 2)}

Intestinal biopsies (Fig. 2). Prechallenge biopsies were normal in all but 2 of the 32 patients studied. The two abnormal biopsies (1 showing 'subtotal' and 1 showing 'partial villous atrophy') were from children who had regular lapses from the diet. Both their postchallenge biopsies were completely flat.

The first 2 children in the study (Cases 8 and 9, Table 2) had postchallenge biopsies 8 to 9 weeks after reintroduction of gluten. In one the biopsy was normal and in the other there were only minor abnormalities. For this reason, in all subsequent cases the challenge period was extended to at least 12 weeks in the absence of definite symptonis.

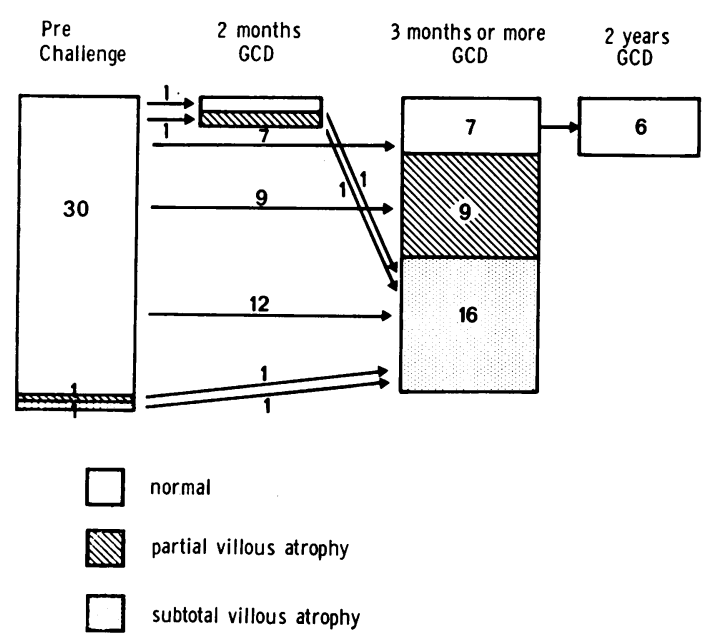

Fig. 2 Jejunal biopsy appearances. 
Table 2 Clinical details and laboratory investigations

\begin{tabular}{|c|c|c|c|c|c|c|c|c|c|c|c|}
\hline \multirow{3}{*}{$\begin{array}{l}\text { Case } \\
\text { no. }\end{array}$} & \multirow{3}{*}{$\begin{array}{l}\text { Age } \\
\text { (years) }\end{array}$} & \multirow{3}{*}{$\begin{array}{l}\text { Onset of } \\
\text { symptoms } \\
\text { (years) }\end{array}$} & \multirow{3}{*}{ Original symptoms } & \multirow{3}{*}{$\begin{array}{l}\text { Gluten- } \\
\text { free diet } \\
\text { (years) }\end{array}$} & \multirow{3}{*}{$\begin{array}{l}\text { Gluten- } \\
\text { containing } \\
\text { diet }(w)\end{array}$} & \multicolumn{2}{|c|}{ Postchallenge } & \multirow{3}{*}{$\begin{array}{l}\text { Symptoms during } \\
\text { challenge }\end{array}$} & \multirow{2}{*}{\multicolumn{3}{|c|}{$\begin{array}{l}\text { Biopsy } \\
\text { appearance }\end{array}$}} \\
\hline & & & & & & Serum & $R B C$ & & & & \\
\hline & & & & & & $\begin{array}{l}\text { folate } \\
(5 \cdot 9-21 \\
n g / m l)\end{array}$ & $\begin{array}{l}\text { folate } \\
(150-650 \\
n g / m l)\end{array}$ & & lst & 2nd & $3 r d$ \\
\hline 1 & $6 \cdot 8$ & 0.6 & $\begin{array}{l}\text { Persistent loose stool, } \\
\text { poor weight gain }\end{array}$ & $5 \cdot 7$ & $13 \cdot 3 ; 106 \cdot 3$ & $10 \cdot 4$ & 301 & Irritable & $\mathbf{N}$ & $\mathbf{N}$ & $\mathbf{N}$ \\
\hline 2 & $15 \cdot 0$ & 0.3 & $\begin{array}{l}\text { Bulky offensive stool, } \\
\text { weight loss, abdominal } \\
\text { distension }\end{array}$ & $6 \cdot 8$ & $17 \cdot 4 ; 116 \cdot 8$ & $16 \cdot 0$ & 311 & Lethargy & ", & ", & $"$ \\
\hline 3 & $10 \cdot 3$ & $0 \cdot 3$ & $\begin{array}{l}\text { Loose offensive stool, } \\
\text { abdominal distension }\end{array}$ & $7 \cdot 8$ & $12 \cdot 0 ; 110 \cdot 0$ & $3 \cdot 6$ & 357 & Nil & & ", & ", \\
\hline 4 & $7 \cdot 2$ & $0 \cdot 3$ & $\begin{array}{l}\text { Diarrhoea, wasting, pot } \\
\text { belly, misery }\end{array}$ & $6 \cdot 7$ & $13 \cdot 0 ; 108 \cdot 4$ & $6 \cdot 1$ & 257 & $"$ & " & ", & ," \\
\hline 5 & $3 \cdot 1$ & $0 \cdot 2$ & $\begin{array}{l}\text { Severe diarrhoea, } \\
\text { multiple intolerance }\end{array}$ & $2 \cdot 3$ & $12 \cdot 2 ; 123 \cdot 0$ & & & & ", & & \\
\hline 6 & $6 \cdot 1$ & $1 \cdot 3$ & Frequent loose stools & $4 \cdot 0$ & $13 \cdot 1 ;-$ & & 309 & $\begin{array}{l}\text { Oral ulcers, } \\
\text { abdominal pain }\end{array}$ & & & $"$ \\
\hline 7 & $\begin{array}{r}14 \cdot 2 \\
7 \cdot 8\end{array}$ & 1.4 & $\begin{array}{l}\text { Short stature, abdominal } \\
\text { pain, family history } \\
\text { Anaemia, D\&V, weight }\end{array}$ & $6 \cdot 0$ & $15 \cdot 3 ; 105 \cdot 0$ & $4 \cdot 0$ & 199 & Flatulence & " & ", & $"$ \\
\hline & & & $\begin{array}{l}\text { loss, abdominal } \\
\text { distension }\end{array}$ & $6 \cdot 3$ & $8 \cdot 7 ; 31 \cdot 1$ & $2 \cdot 7 ; 1 \cdot 8$ & 240,83 & $\begin{array}{l}\text { Irritable, abdominal } \\
\text { pain, weight loss }\end{array}$ & & & $\mathbf{F}$ \\
\hline 9 & $11 \cdot 3$ & 0.6 & $\mathbf{D} \& \mathbf{V}$ & $10 \cdot 3$ & $8 \cdot 9 ; 15 \cdot 3$ & $6 \cdot 4 ; 4 \cdot 8$ & 293,112 & $\begin{array}{l}\text { Tired, anorexic, } \\
\text { moody, headache }\end{array}$ & ", & P & $\mathbf{F}$ \\
\hline 10 & $7 \cdot 3$ & $0 \cdot 3$ & $\begin{array}{l}\text { Fatty offensive stool, } \\
\text { lethargy, abdominal } \\
\text { distension }\end{array}$ & $6 \cdot 8$ & $12 \cdot 0$ & $4 \cdot 9$ & 160 & Nil & ", & ,. & \\
\hline 11 & $10 \cdot 0$ & $5 \cdot 0$ & $\begin{array}{l}\text { Diarrhoea, weight loss, } \\
\text { irritability }\end{array}$ & $1 \cdot 7$ & $12 \cdot 3$ & $5 \cdot 4$ & 226 & Nil & & & \\
\hline 12 & $5 \cdot 5$ & 0.5 & $\begin{array}{l}\text { Vomiting, loose stools, } \\
\text { weight loss, abdominal } \\
\text { distension }\end{array}$ & $4 \cdot 3$ & $12 \cdot 4$ & $4 \cdot 2$ & 150 & Oral ulceration & $"$ & ", & \\
\hline 13 & 13 & 0.9 & $\begin{array}{l}\text { Offensive stools, anorexia } \\
\text { weight loss }\end{array}$ & ${ }^{a} \cdot 0$ & $12 \cdot 9$ & $2 \cdot 0$ & 170 & $\begin{array}{l}\text { Offensive stool, } \\
\text { abdominal pain, } \\
\text { oral ulcers }\end{array}$ & ", & $\mathbf{F}$ & \\
\hline 15 & $14 \cdot 5$ & $1 \cdot 0$ & $\begin{array}{l}\text { Weight loss, abdominal } \\
\text { pain \& distension, } \\
\text { irritable, frequent } \\
\text { stools }\end{array}$ & $8 \cdot 0$ & $12 \cdot 4$ & 11 & 134 & 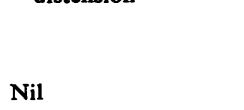 & $\mathbf{F}$ & $\mathbf{F}$ & \\
\hline 16 & $14 \cdot 6$ & 0.4 & $\begin{array}{l}\text { Vomiting, irritable, } \\
\text { frequent stools }\end{array}$ & $8 \cdot 0$ & $12 \cdot 3$ & 7 & 165 & Slight abdominal pain & $\mathbf{N}$ & $\mathbf{P}$ & \\
\hline 17 & $5 \cdot 2$ & $\mathbf{0 \cdot 3}$ & $\begin{array}{l}\text { Diarrhoea, wasting, } \\
\text { abdominal distension }\end{array}$ & $4 \cdot 5$ & $13 \cdot 0$ & $4 \cdot 3$ & 121 & - & , & ", & \\
\hline 18 & $15 \cdot 3$ & $1 \cdot 5$ & $\begin{array}{l}\text { Anorexia, weight loss, } \\
\text { lethargy, offensive } \\
\text { stools }\end{array}$ & $4 \cdot 0$ & $10 \cdot 1$ & $3 \cdot 2$ & 98 & GI upset slight & , & $\mathrm{F}$ & \\
\hline 19 & $12 \cdot 6$ & $8 \cdot 0$ & $\begin{array}{l}\text { Growth poor, weight loss, } \\
\text { loose stools, anaemia }\end{array}$ & $4 \cdot 0$ & $22 \cdot 3$ & $32 ; 16 \cdot 3$ & 650 & $\begin{array}{l}\text { Offensive stool, } \\
\text { irritable, vomiting }\end{array}$ & , & ", & \\
\hline 20 & $4 \cdot 0$ & 0.4 & $\begin{array}{l}\text { Loose stools, weight loss, } \\
\text { vomiting, misery }\end{array}$ & $3 \cdot 0$ & $22 \cdot 9$ & $21 \cdot 6 ; 6 \cdot 7$ & 217 & $\begin{array}{l}\text { Offensive stool, } \\
\text { abdominal disten- } \\
\text { sion }\end{array}$ & , & ". & \\
\hline 21 & $10 \cdot 6$ & $1 \cdot 0$ & $\begin{array}{l}\text { Irritable, poor weight } \\
\text { gain, D\&V, } \\
\text { constipation }\end{array}$ & $1 \cdot 6$ & $12 \cdot 1$ & 16 & 640 & (20) & , & $\mathbf{P}$ & \\
\hline 22 & $12 \cdot 8$ & 0.5 & $\begin{array}{l}\text { Loose stools, weight loss, } \\
\text { irritable }\end{array}$ & $6 \cdot 7$ & $11 \cdot 0$ & & & Anorexia & , & ", & \\
\hline 23 & $5 \cdot 4$ & 0.4 & $\begin{array}{l}\text { Diarrhoea, weight loss, } \\
\text { lethargy }\end{array}$ & $5 \cdot 0$ & $11 \cdot 1$ & $3 \cdot 2$ & & Nil & ". & ", & \\
\hline 24 & $7 \cdot 2$ & 0.4 & $\begin{array}{l}\text { Vomiting, weight loss, } \\
\text { pale bulky stools }\end{array}$ & 6.5 & $14 \cdot 0$ & $9 \cdot 8$ & 298 & Occasional colic & ", & , & \\
\hline 25 & $10 \cdot 3$ & 0.6 & $\begin{array}{l}\text { Vomiting, loose stools, } \\
\text { weight loss, abdominal } \\
\text { distension }\end{array}$ & $7 \cdot 7$ & $13 \cdot 1$ & $3 \cdot 0$ & & $\begin{array}{l}\text { Irritable, occasional } \\
\text { colic }\end{array}$ & , & $\mathbf{F}$ & \\
\hline 26 & $9 \cdot 5$ & $1 \cdot 0$ & $\begin{array}{l}\text { Vomiting, mild } \\
\text { diarrhoea }\end{array}$ & $8 \cdot 2$ & $12 \cdot 7$ & & 210 & $\begin{array}{l}\text { Anorexia, abdominal } \\
\text { pain, diarrhoea }\end{array}$ & , & ", & \\
\hline
\end{tabular}


Table 2 Clinical details and laboratory investigations-cont.

\begin{tabular}{|c|c|c|c|c|c|c|c|c|c|c|}
\hline \multirow{2}{*}{$\begin{array}{l}\text { Case } \\
\text { no. }\end{array}$} & \multirow{2}{*}{$\begin{array}{l}\text { Age } \\
\text { (years) }\end{array}$} & \multirow{2}{*}{$\begin{array}{l}\text { Onset of } \\
\text { symptoms } \\
\text { (years) }\end{array}$} & \multirow[t]{2}{*}{ Original symptoms } & \multirow{2}{*}{$\begin{array}{l}\text { Gluten- } \\
\text { free diet } \\
\text { (years) }\end{array}$} & \multirow{2}{*}{$\begin{array}{l}\text { Gluten- } \\
\text { containing } \\
\text { diet }(w)\end{array}$} & \multicolumn{2}{|c|}{ Postchallenge } & \multirow{2}{*}{$\begin{array}{l}\text { Symptoms during } \\
\text { challenge }\end{array}$} & \multicolumn{2}{|c|}{$\begin{array}{l}\text { Biopsy } \\
\text { appearance }\end{array}$} \\
\hline & & & & & & $\begin{array}{l}\text { Serum } \\
\text { folate } \\
(5 \cdot 9-21 \\
n g / m l)\end{array}$ & $\begin{array}{l}R B C \\
\text { folate } \\
(150-650 \\
n g / m l)\end{array}$ & & $1 s t$ & 2nd $3 r d$ \\
\hline 27 & $12 \cdot 9$ & 0.5 & $\begin{array}{l}\text { Abdominal distension, } \\
\text { loose bulky stools, } \\
\text { thin, pale }\end{array}$ & 11.0 & 12.7 & 4.1 & 301 & Nil & $\mathbf{N}$ & $\mathbf{F}$ \\
\hline 28 & $10 \cdot 4$ & 0.6 & $\begin{array}{l}\text { Weight loss, vomiting, } \\
\text { bulky stools, retardatio } \\
\text { hypotonia }\end{array}$ & $9 \cdot 5$ & $12 \cdot 3$ & $3 \cdot 1$ & 225 & Abdominal pain $\times 1$ & $"$ & " \\
\hline 29 & $12 \cdot 0$ & $3 \cdot 0$ & $\begin{array}{l}\text { Loose stools, weight loss, } \\
\text { abdominal distension } \\
\text { Failure to thrive, }\end{array}$ & 4.8 & $13 \cdot 1$ & $2 \cdot 2$ & 158 & (1) & $\mathbf{P}$ & " \\
\hline 31 & $13 \cdot 8$ & 5.0 & $\begin{array}{l}\text { diarrhoea, abdominal } \\
\text { distension } \\
\text { Diarrhoea, delayed }\end{array}$ & $10 \cdot 3$ & $12 \cdot 1$ & $4 \cdot 2$ & 193 & Nil & $\mathbf{N}$ & $\mathbf{P}$ \\
\hline$\pi$ & 1000 & J.0 & puberty & 0.25 & 16.0 & $2 \cdot 8$ & 560 & $\begin{array}{l}\text { Nightmares, abdomina } \\
\text { pain }\end{array}$ & al & $\mathbf{F}$ \\
\hline 32 & $14 \cdot 3$ & $1 \cdot 2$ & $\begin{array}{l}\text { Abdominal distension, } \\
\text { loose offensive stools, } \\
\text { anorexia, lethargy }\end{array}$ & 9.2 & $12 \cdot 3$ & 3.4 & 209 & 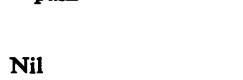 & n & $\mathbf{F}$ \\
\hline
\end{tabular}

$\mathrm{N}=$ normal; $\mathrm{P}=$ partial villous atrophy; $\mathrm{F}=$ subtotal villous atrophy.

The two children biopsied at 8 weeks had third biopsies after 12 or more weeks of gluten challenge which were completely flat. Of the remaining 30 patients, 12 had subtotal and 11 had partial villous atrophy on postchallenge biopsy. In 7 patients postchallenge biopsies were normal. Thus of the original 32 patients, gluten-induced mucosal abnormalities were shown in 25 . There was no relationship between the amount of gluten ingested and the severity of histological changes in the postchallenge biopsy.

The 7 patients with normal biopsies after 12 weeks' gluten challenge remained on a gluten-containing diet for a further 2 years and 6 were then rebiopsied. All these biopsies were normal. The seventh child (Case 7, Table 2) remains symptom free and is growing normally after 4 years' gluten ingestion. Only 2 children in this group had biopsies before this study: one was doubtfully abnormal; the other, taken after 3 months on a GFD, was normal.

Haematological effects of gluten challenge. Although serum folate levels tended to fall during the gluten challenge, in only 5 of the 25 patients who were proved to have coeliac disease did they become abnormal. RBC folate levels remained normal in the 7 patients whose biopsies remained normal after gluten challenge. The effects of the gluten challenge on RBC levels in 19 of the remaining 25 patients are shown in Fig. 3. Levels fell in 17 of the 19 patients, and were frankly abnormal in 5. In 2 patients RBC folate increased during the challenge. Both $\mathrm{Hb}$ and serum iron concentrations were unaffected by the challenge.

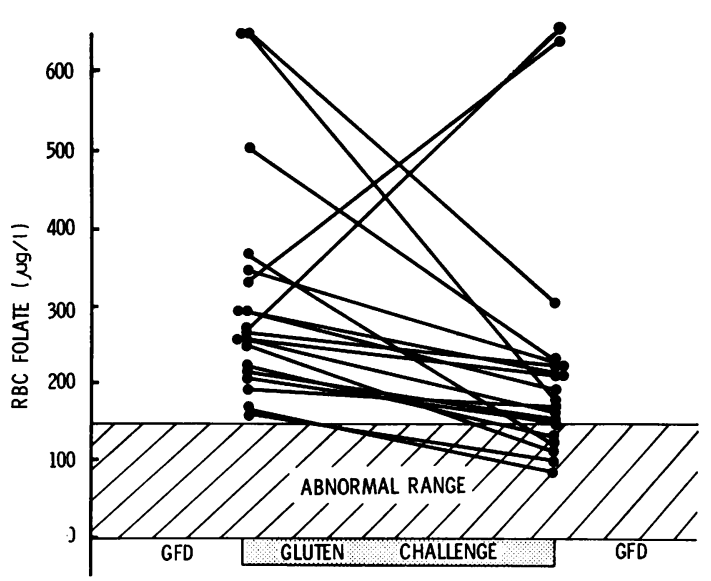

Fig. 3 Effects of gluten challenge on $R B C$ folate concentrations.

Clinical effects of gluten challenge. This part of the study was designed to assess the relationship between symptoms or signs developing during the challenge period and the appearances of the postchallenge biopsy. The patients have been grouped as having no symptoms, equivocal symptoms, or definite symptoms and signs as shown in Table 3. The development of symptoms was a very unreliable indicator of whether the patient had coeliac disease. $10(40 \%)$ of the children who were shown to have coeliac disease remained completely asymptomatic during the challenge period, and only 4 developed definite symptoms and signs. Equivocal symptoms 
Table 3 Clinical effects of gluten challenge

\begin{tabular}{lcccc}
\hline & \multicolumn{3}{l}{ Symptoms or signs } \\
\cline { 2 - 4 } & None & Equivocal* & Definite $\dagger$ \\
\hline Abnormal postchallenge biopsy & 10 & 11 & 4 \\
Normal postchallenge biopsy & 3 & 4 & 0 \\
\hline
\end{tabular}

Numbers refer to number of patients.

*Equivocal = transient loose stools or abdominal pain; mild irritability or anorexia.

tDefinite = sustained change in stool frequency and/or appearance; abdominal distension; anorexia ; marked irritability and mood change; weight loss.

usually occurred within the first few weeks of the challenge, and with reassurance, were transient in most cases.

Social and emotional effects of gluten challenge. Questionnaires were sent to the first $\mathbf{3 0}$ families in the study and replies were received from 26 . Families not responding had children aged $5 \cdot 5,7,8$, and 14 years; all had uneventful admissions and a diagnosis of coeliac disease was established in each case. The 3 younger children were later seen for follow-up, when their parents considered that they had not been particularly upset by the hospital admissions and that their subsequent behaviour had been normal. These 4 children are excluded from further discussion.

A diagnosis of coeliac disease was confirmed in 19 of the 26 patients. The results of the questionnaire are shown in Table 4. The children have been grouped according to age, since problems encountered in

Table 4 Results of questionnaire

\begin{tabular}{|c|c|c|}
\hline & \multicolumn{2}{|l|}{ Age (years) } \\
\hline & $<8(n=7)$ & $>9(n=19)$ \\
\hline \multicolumn{3}{|l|}{ Home behaviour } \\
\hline \multicolumn{3}{|l|}{ Apprehensive of: } \\
\hline 1st admission & 3 & 2 \\
\hline 2nd admission & 2 & 4 \\
\hline 3 rd admission ( 5 children) & 2 & $\mathbf{0}$ \\
\hline Upset on return home & 2 & $\mathbf{0}$ \\
\hline \multicolumn{3}{|l|}{ Reaction to biopsy procedure } \\
\hline \multicolumn{3}{|l|}{ Frightened of: } \\
\hline 1st biopsy & 4 & 7 \\
\hline 2nd biopsy - worse & 2 & 4 \\
\hline - better & 2 & $\mathbf{0}$ \\
\hline 3rd biopsy - worse & 0 & $\mathbf{0}$ \\
\hline - better & 3 & 2 \\
\hline Persistent fear of biopsy & 2 & 0 \\
\hline \multicolumn{3}{|l|}{ Reactions to dietary changes } \\
\hline \multicolumn{3}{|l|}{ Problems during challenge: } \\
\hline $\begin{array}{l}\text { symptoms } \\
\text { dislike }\end{array}$ & 1 & 5 \\
\hline dislike & 1 & 5 \\
\hline anxiety & 2 & 2 \\
\hline \multicolumn{3}{|l|}{ Difficulties on return to gluten-free diet: } \\
\hline problems & 2 & 2 \\
\hline no problems & 2 & 13 \\
\hline \multicolumn{3}{|l|}{ Children remaining on gluten-containing } \\
\hline diet & 3 & 4 \\
\hline
\end{tabular}

children under the age of 8 years were often very different from those in older children.

Apprehension at home before the first admission was mainly due to anxiety about the biopsy, particularly in the younger children. In general, subsequent admissions did not increase apprehension. 2 of the younger children were upset on returning home after one or more admissions, whereas none of the older children was affected.

After careful explanation and with appropriate sedation when necessary, all children tolerated the biopsy procedure remarkably well. 4 of the younger children and 7 of the older group were frightened during the first biopsy; 2 of the younger group were less frightened by the second biopsy as was the case for all 5 children requiring a third biopsy. Delay in progress of the capsule was the chief source of anxiety during the biopsy procedure. 2 of the younger children had a persistent fear of the biopsies while this did not happen with the older children.

Gastrointestinal symptoms, dislike of glutencontaining foods, or anxiety about their possible effects were common in both age groups during the gluten-challenge period. Despite reassurance, both parents and children were apprehensive about the possibility of acute illness at the start of the challenge, although this never occurred. Difficulty in returning to a strict GFD was commoner in the younger children. With two exceptions the older children were disappointed with the gluten-containing foods and returned to their diet without regret. Needles, particularly finger pricks, were the chief source of remembered distress in all children. 6 children regularly ate oats (e.g. porridge) throughout the year. All had normal prechallenge biopsies and in 5 the diagnosis of coeliac disease was confirmed.

\section{Discussion}

Ideally coeliac disease is confirmed by biopsy at the time of initial diagnosis. However, this may sometimes not be practical in young sick infants. Early introduction of mixed feeding may have resulted in some coeliac children presenting at an earlier age when, because of their small size and often poor physical condition, biopsy may very occasionally be considered unwise. It should be stressed, however, that biopsy before introducing a GFD is an important diagnostic criterion. In young sick infants this procedure should be performed in experienced centres in order to minimise complications. Also other conditions which may produce mucosal abnormalities similar to those seen in coeliac disease are commoner in children under 1 year (Anderson et al., 1972) and confirmation of the diagnosis should be undertaken later, before commitment to a life-long GFD. 


\section{Packer, Charlton, Keeling, Risdon, Ogilvie, Rowlatt, Larcher, and Harries}

Of the 31 patients who had been receiving a GFD for a mean period of 6.5 years, 24 were shown to have coeliac disease by gluten challenge. 6 of the remaining 7 had normal biopsies after ingestion of at least $10 \mathrm{~g}$ gluten per day for 2 years, and may be considered not to have coeliac disease. In 1 of these 7 children previous biopsy had been reported as abnormal, but we were unable to confirm the original report. This emphasises the need for experienced interpretation of biopsies before committing patients to gluten-free diets for life. Objective methods of assessing mucosal morphology may be helpful in this respect (Risdon and Keeling, 1974).

The nature and optimal duration of a gluten challenge are controversial topics and have not been clearly defined (McNeish, 1968; Hamilton and McNeill, 1972; Rolles et al., 1975). Rolles et al. (1975) gave $20 \mathrm{~g}$ per day commercial gluten powder to their patients, whereas Hamilton and McNeill (1972) used one slice of bread per day (approximately $2.5 \mathrm{~g}$ gluten). In most other studies in children the daily intake of gluten has not been controlled. It has been suggested that the administration of commercial gluten powder prevents the child becoming accustomed to gluten-containing foods and the possible difficulties of returning to a GFD after a positive challenge (Rolles et al., 1975) are avoided. Only 4 of 19 patients specifically questioned experienced such difficulties in our study.

The earliest mucosal changes induced by gluten in coeliac disease require electronmicroscopy or enzyme histochemistry for their definition (Bayless et al., 1970). Our aim was to establish the time interval required after the reintroduction of dietary gluten for the development of unequivocal changes easily demonstrable by light microscopy. The results indicate that for practical purposes a normal biopsy after a 3- to 4-month gluten challenge of at least $10 \mathrm{~g}$ natural gluten excludes a diagnosis of coeliac disease. Where, as in this study, prechallenge 'control' biopsies are available for comparison, accurate assessment of the mucosal lesion may be aided by the application of morphometric techniques.

Because of the variation in time required for gluten to induce mucosal changes, a reliable symptom or screening test would be useful as an aid to timing of the second biopsy. In this study development of symptoms and signs during the challenge period was a very unreliable indication of gluten-induced mucosal abnormalities. Only 4 coeliacs developed definite clinical manifestations. Equivocal symptoms such as 'loose' stools, vague abdominal pain, and mild irritability were common during the first week or two after reintroducing gluten in children with both normal and abnormal postchallenge biopsies and in the majority of patients these resolved after reassurance.
Such symptoms are presumably related to apprehension and are not an indication for bringing forward the second biopsy. Rolles et al. (1975) found in young infants that the clinical response to a gluten challenge was much more rapid, but in our study there was no relationship between age at biopsy and severity of biopsy changes.

The 1-hour blood xylose test has been reported as a useful procedure in the timing of postchallenge biopsies (Rolles et al., 1975) but this has not been our experience (Lamabadusuriya et al., 1975). In the present study both $\mathrm{Hb}$ and serum iron values were unaffected by gluten challenge. As judged by oral load tests, absorption of folic acid is impaired in adults with 'idiopathic sprue' (Chanarin and Bennett, 1962) and coeliac disease (Hoffbrand et al., 1970). McNeish and Willoughby (1969) measured whole-blood folate levels, which mainly reflects red cell folate, in 30 children with untreated coeliac disease, and found it to be reduced in all patients; serum folate was also reduced in all these patients, but it was also low in 5 of 12 control subjects. In this study we measured pre- and postchallenge serum and $\mathrm{RBC}$ folate concentrations. Of the patients who were shown to have coeliac disease, serum and RBC folate fell to abnormal levels in 7 and 8 patients respectively, suggesting that the symptoms and screening tests of a gluten challenge are unreliable in predicting which patients will develop gluteninduced enteropathy. Our patients had received a GFD for a mean period of 6.5 years, and the mean age at the onset of gluten challenge was 9.9 years. In children of this age who have received dietary treatment for several years we would recommend a 3- to 4-month period of gluten ingestion; the finding of a normal postchallenge biopsy excludes coeliac disease. We suggest, however, that they be followed up for a further 2 years and, in accordance with the international study (Meeuwisse, 1970), rebiopsed at this time.

The social and emotional impact of a gluten challenge was assessed by means of a questionnaire sent to the parents after the child's second admission. Apprehension at home before admission was due mainly to anxiety of the biopsy procedure itself, particularly in younger children. All children tolerated the biopsy procedure well. 2 of the younger children had a persistent fear of biopsies, while this was not the case in any of the older children. Needles, not the biopsy procedure, were the chief source of remembered distress in all children. In the majority of the older children no problems were encountered on returning to a GFD whereas difficulties were common in the younger age group. Careful explanation of the biopsy procedure to the child and parents by the person who actually 
performed the biopsy was important in preparing the whole family for the child's admission, This was particularly the case in the younger children who were much more dependent on their parents for reassurance and explanation at all stages. The older children were able to understand the reason for the biopsies and challenge, and this was reflected in an extraordinary degree of co-operation in all aspects of the study.

The optimal age for gluten challenge is controversial. Early challenge would resolve dietary difficulties encountered with school lunches and parties and for some children would eliminate many years of unnecessary treatment. The major objection is the emotional stress to the young child compared with the older one, and the resulting demands on the family. Challenge in older children has the advantage of considerably greater understanding and co-operation from the child, and less stress for the rest of the family. The planning of a challenge at any age should take into consideration the known emotional requirements of children at different ages, and should also recognise the anxiety and stress which may be felt by the whole family. The performance of biopsies on a day-care basis may reduce these anxieties and stresses, but requires evaluation.

The exclusion of oats and barley from the diet of a child with coeliac disease remains controversial (Anderson et al., 1972). Dissanayake et al. (1974) administered 40-60 g porridge oats for 1 month to adults with coeliac disease. The patients remained symptom free, and jejunal biopsies were normal after the challenge; the authors concluded that oats are harmless to coeliac subjects and can be included in a GFD. Mucosal damage may be delayed (Case 9) but in the present study 5 children, who were proved to have coeliac disease and who had normal prechallenge biopsies, had regularly eaten oats for at least a year before the challenge. These findings tend to support the observations of Dissanayake et al. (1974).

S.M.P. gratefully acknowledges the Wellcome Trust for financial support.

\section{References}

Anderson, C. M., Gracey, M., and Burke, V. (1972). Coeliac disease. Some still controversial aspects. Archives of Disease in Childhood, 47, 292-298.

Barry, R. E., and Read, A. E. (1973). Coeliac disease and malignancy. Quarterly Journal of Medicine, 168, 665-675.
Bayless, T. M., Rubin, S. E., Topping, T. M., Yardley, J. H., and Hendrix, T. R. (1970). Morphological and functional effects of gluten feeding on jejunal mucosa in coeliac disease. Coeliac Disease, pp. 78-79. Ed. by C. C. Booth and R. H. Dowling. Churchill Livingstone, London.

Chanarin, I., and Bennett, M. C. (1962). Absorption of folic acid and $D$-xylose as tests of small intestinal function. British Medical Journal, 1, 985-989.

Dissanayake, A. S., Truelove, S. C., and Whitehead, R. (1974). Lack of harmful effect of oats on small intestinal mucosa in coeliac disease. British Medical Journal, 4, 189-191.

Hamilton, J. R., and McNeill, L. K. (1972). Childhood celiac disease: response of treated patients to a small uniform daily dose of wheat gluten. Journal of Pediatrics, 81, 885-893.

Harris, O. D., Cooke, W. T., Thomson, H., and Waterhouse, J. A. H. (1967). Malignancy in adult coeliac disease and idiopathic steatorrhoea. American Journal of Medicine, 42, 899-912.

Hoffbrand, A. V., Douglas, A. P., Fry, L., and Stewart, J. S. (1970). Malabsorption of dietary folate (pteroylpolyglutamates) in adult coeliac disease and dermatitis herpetiformis. British Medical Journal, 4, 85-89.

Holmes, G. K. T., Stokes, P. L., Sorahan, T. M., Prior, P., Waterhouse, J. A. H., and Cooke, W. T. (1976). Coeliac disease, gluten free diet, and malignancy. Gut, 17, 612-619.

Lamabadusuriya, S. P., Packer, S., and Harries, J. T. (1975). Limitations of xylose tolerance test as a screening procedure in childhood coeliac disease. Archives of Disease in Childhood, 50, 34-39.

McNeish, A. S. (1968). Diagnosis of coeliac disease in retrospect. Archives of Disease in Childhood, 43, 362-364.

McNeish, A. S., and Willoughby, M. L. N. (1969). Wholeblood folate as a screening test for coeliac disease in childhood. Lancet, 1, 442-443.

Meeuwisse, G. W., (1970). Diagnostic criteria in coeliac disease. Acta Paediatrica Scandinavica, 59, 461-463.

Mortimer, P. E., Stewart, J. S., Norman, A. P., and Booth, C. C. (1968). Follow up study of coeliac disease. British Medical Journal, 3, 7-9.

Risdon, R. A., and Keeling, J. W. (1974). Quantitation of the histological changes found in small intestinal biopsy specimens from children with suspected coeliac disease. Gut, 15, 9-18.

Risdon, R. A., Meinhard, E. A., Wadbrook, D. G., and Keeling, J. W. (1975). Small intestinal biopsy in childhood coeliac disease. Postgraduate Medical Journal, 51, 716-721.

Rolles, C. J., Anderson, C. M., and McNeish, A. S. (1975). Confirming persistence of gluten intolerance in children diagnosed as having coeliac disease in infancy. Archives of Disease in Childhood, 50, 259-263.

Sheldon, W. (1969). Prognosis in early adult life of coeliac children treated with a gluten free diet. British Medical Journal, 2, 401-404.

Young, W. F., and Pringle, E. M. (1971). 110 children with coeliac disease, 1950-1969. Archives of Disease in Childhood, 46, 421-436.

Correspondence to Dr J. T. Harries, Department of Child Health, Institute of Child Health, 30 Guilford Street, London WC1N 1EH. 